\title{
Influence of gaseous ozone in peri-implantitis: bactericidal efficacy and cellular response. An in vitro study using titanium and zirconia
}

\author{
Irmgard Hauser-Gerspach • Jasminka Vadaszan • Irma Deronjic • Catiana Gass • \\ Jürg Meyer • Michel Dard • Tuomas Waltimo • Stefan Stübinger • Corinna Mauth
}

Received: 2 February 2011 /Accepted: 3 August 2011 / Published online: 13 August 2011

(C) Springer-Verlag 2011

\begin{abstract}
Dental implants are prone to bacterial colonization which may result in bone destruction and implant loss. Treatments of peri-implant disease aim to reduce bacterial adherence while leaving the implant surface intact for attachment of bone-regenerating host cells. The aims of this study were to investigate the antimicrobial efficacy of gaseous ozone on bacteria adhered to various titanium and zirconia surfaces and to evaluate adhesion of osteoblast-like MG-63 cells to ozone-treated surfaces. Saliva-coated titanium (SLA and polished) and zirconia (acid etched and polished) disks served as substrates for the adherence of Streptococcus sanguinis DSM20068 and Porphyromonas gingivalis ATCC33277. The test specimens were treated with gaseous ozone (140 ppm; $33 \mathrm{~mL} / \mathrm{s})$ for 6 and $24 \mathrm{~s}$. Bacteria were resuspended using ultrasonication, serially
\end{abstract}

I. Hauser-Gerspach · J. Vadaszan · J. Meyer · T. Waltimo Institute of Preventive Dentistry and Oral Microbiology, School of Dental Medicine, University of Basel, Hebelstrasse 3,

4056 Basel, Switzerland

I. Deronjic $\cdot$ C. Gass $\cdot$ S. Stübinger

Competence Center for Applied Biotechnology and Molecular

Medicine, University of Zürich,

Winterthurerstrasse 190,

8057 Zürich, Switzerland

M. Dard $\cdot$ C. Mauth

Institut Straumann AG,

Peter Merian-Weg 12,

4052 Basel, Switzerland

I. Hauser-Gerspach $(\bowtie)$

Institut für Präventivzahnmedizin und Orale Mikrobiologie,

Universitätskliniken für Zahnmedizin,

Hebelstrasse 3,

CH-4056 Basel, Switzerland

e-mail: I.Hauser-Gerspach@unibas.ch diluted and cultured. MG-63 cell adhesion was analyzed with reference to cell attachment, morphology, spreading, and proliferation. Surface topography as well as cell morphology of the test specimens were inspected by SEM. The highest bacterial adherence was found on titanium SLA whereas the other surfaces revealed 50-75\% less adherent bacteria. P. gingivalis was eliminated by ozone from all surfaces within $24 \mathrm{~s}$ to below the detection limit ( $\geq 99.94 \%$ reduction). S. sanguinis was more resistant and showed the highest reduction on zirconia substrates $(>90 \%$ reduction). Ozone treatment did not affect the surface structures of the test specimens and did not influence osteoblastic cell adhesion and proliferation negatively. Titanium (polished) and zirconia (acid etched and polished) had a lower colonization potential and may be suitable material for implant abutments. Gaseous ozone showed selective efficacy to reduce adherent bacteria on titanium and zirconia without affecting adhesion and proliferation of osteoblastic cells. This in vitro study may provide a solid basis for clinical studies on gaseous ozone treatment of peri-implantitis and revealed an essential base for sufficient tissue regeneration.

Keywords Peri-implantitis · Titanium · Zirconia Gaseous ozone $\cdot$ Decontamination

\section{Introduction}

Long-term observations of osseointegrated dental implants have indicated high survival rates [1-3]. However, current literature depicts that one of the future problems of a society with an increasing proportion of elderly patients will be a progressive loss of hard and soft tissue attachment around dental implants due to peri-implant infections [4]. Peri-implantitis is a bacterial infection characterized by 
inflamed, swollen, and bleeding soft tissues resulting in suppuration and crater-like destruction of adjacent alveolar bone of an implant in function $[5,6]$.

Since bacterial adhesion and colonization has been implicated to be the main causative factor for the initiation and progression of peri-implant disease, the implant and periodontal structures need to be protected from bacterial invasion and subsequent infection [7]. The initial treatment of peri-implant infections therefore is based first on the control of the adhered bacterial cells like the prevention of early colonization [8] and second on decontamination after colonization had already occurred. Bacterial colonization may be prevented or reduced by different surface properties of the material and/or by the use of antiseptic surface coatings $[9,10]$. For decontamination of dental implants, mechanical instruments like dental curettes, ultrasonic devices and air-powder abrasives, laser treatment, treatment with antiseptics and/or antibiotics are commonly used [1014]. The removal of bacteria from implants with hard mechanical instruments has been reported to be incomplete and time consuming [15]. Laser-assisted peri-implantitis therapy makes great demands on an elaborate selection of proper laser parameters to avoid any inadvertent damage of adjacent hard and soft tissue structures and surface characteristics of the irradiated material $[16,17]$. The use of gaseous ozone offers another treatment option to eliminate bacteria on the implant surface. The bactericidal, virucidal, and fungicidal effects of ozone as well as the therapeutic properties, e.g., stimulating the blood flow, make it beneficial for decontamination [18, 19]. The antimicrobial effects are based on its strong oxidation effects on biological macromolecules, particularly (poly) unsaturated fatty acids and - $\mathrm{SH}$ groups, thus affecting membranes and proteins (enzymes) [20, 21]. For this reason, ozone appears attractive as possible therapeutic agent for inflammatory diseases like peri-implantitis. However, as ozone is also a respiratory irritant, safety aspects have to be considered.

The host response to bacterial colonization in periimplantitis is first of all a mucositis and then a loss of supporting alveolar bone. In this regard, the bone remodeling process is compromised by the contaminated implant surfaces $[22,23]$. As different decontamination treatments can damage the implant surfaces they may also modulate cell interactions and thus could have an influence on the healing of an ailing dental implant. For example, osteoblast-like cells demonstrated higher levels of cell attachment on rough surfaces (e.g., provoked through laser treatment) than they did on smooth surfaces [24]. In case of aqueous ozone, the positive effect on oral tissue healing was demonstrated clinically and histologically [25]. There is little information on how oral cell and tissues behave on dental implants treated with gaseous ozone. Concerning a biomaterial bone interface decontaminated by ozone, data in respect of mineralized hard substances are missing.

In dentistry, titanium is well known and commonly used as implant material whereas zirconia, a ceramic-based material with interesting microstructural properties, has only recently been introduced clinically [26]. However, data about early bacterial colonization on zirconia are scarce.

The goals of this in vitro study were (a) to quantify the antibacterial efficacy of (a commercial) gaseous ozone (generator) applied to Streptococcus sanguinis and Prophyromonas gingivalis adhered to zirconia or titanium disks, using chlorhexidine (CHX) as control, and (b) to determine potential surface alterations after application of gaseous ozone on zirconia and titanium microscopically as well as by interactions with osteoblast-like cells, comparing zirconia and titanium in these parameters.

Figure 1 demonstrates the strategy of the investigations: Bacterial adhesion/early colonization is compared on the implant materials titanium and zirconia using $S$. sanguinis (an early colonizer) and $P$. gingivalis (frequently associated with peri-implantitis). Thereto adhesion is allowed to proceed in the presence of a bacteria saliva serum suspension imitating the post-surgical subgingival situation. Gaseous ozone is applied to evaluate bactericidal effects. Possible surface alterations of the dental implant materials by gaseous ozone are analyzed by scanning electron microscopy (SEM). The influence of ozone-treated materials on adhesion of osteoblastic cells (MG-63) is analyzed with special reference to cell attachment, morphology, spreading, and proliferation. These results are expected to help evaluate gaseous ozone as a potential treatment option for peri-implant disease and to contribute to further applications of zirconia as a new biomaterial in dental implantology.

\section{Materials and methods}

Materials and ozone system

As both, bacterial adhesion and cell behavior are different on smooth and rough surfaces, both types of both materials are included to observe effects of ozone. The test materials (Straumann AG, Basel, Switzerland) were prepared as disks (5.0 $\mathrm{mm}$ in diameter) of titanium and zirconia in two surface qualities each, described in Table 1 and illustrated in Fig. 1. They were sterilized by gamma irradiation, incubated (conditioned) in a sterile saliva serum mixture (10:1, see below) during $15 \mathrm{~min}$ at $35^{\circ} \mathrm{C}$, and then directly used in the microbiological experiments. For the cell experiments, sterile disks were used directly.

Ozone treatment was carried out with an OZOTOP unit (TIP TOP TIPS Sàrl. Rolle, Switzerland; 140 ppm; 2 L/min). 
Fig. 1 Diagram of the study design; see text for explanation; abbreviations of the dental implant materials in Table 1

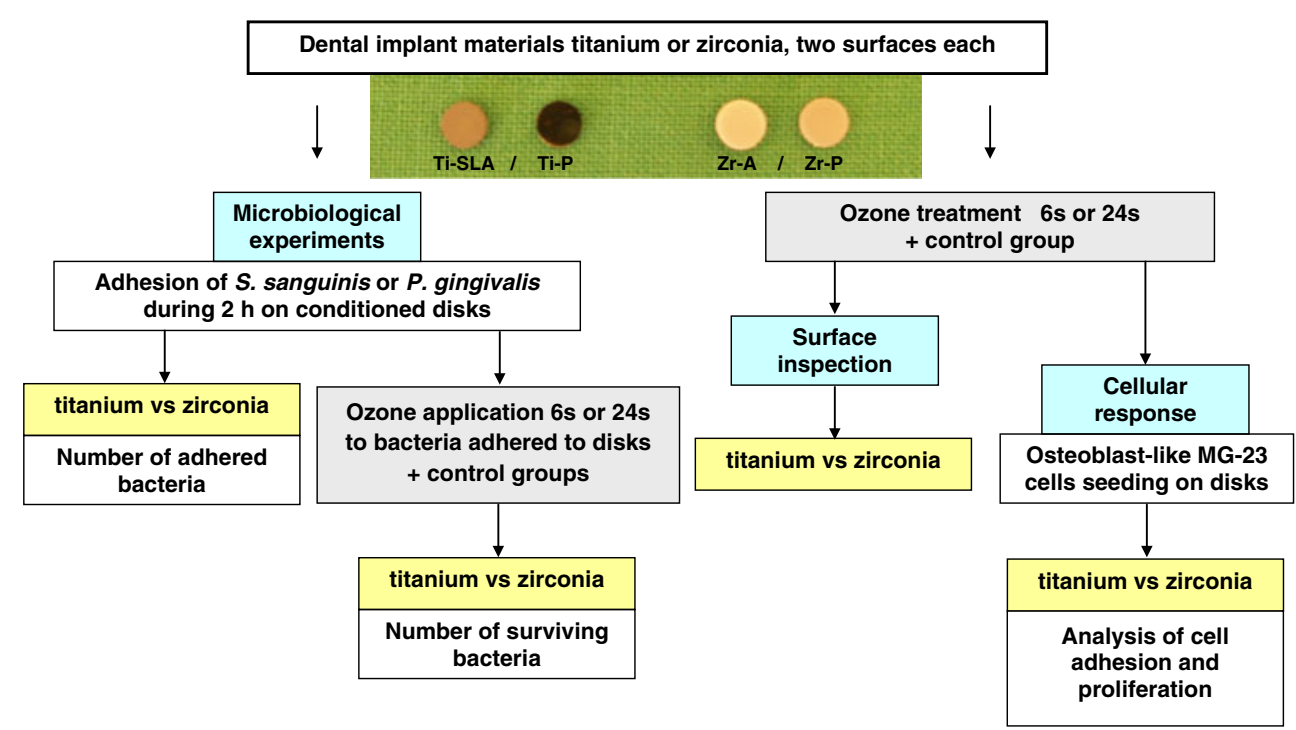

A sterile specially formed perio-tip, attached to the hand piece, was hand-guided over the whole specimen area analogous to clinical procedure. It was applied with the two minimal and maximal treatment times of 6 and $24 \mathrm{~s}$ preselected by the manufacturer.

Surface roughness was quantitated using confocal white light microscopy (QS04358). Three measurements per disks were performed.

\section{Microbiological experiments}

Reference strains of $S$. sanguinis (DSM 20068) and $P$. gingivalis (ATCC 33277) were cultured in Schaedler broth (BBL ${ }^{\mathrm{TM}}$, Becton Dickinson, Basel, Switzerland) and Thioglycolate Vision Broth (Biomérieux, Meyrin, Switzerland), respectively. Human saliva was collected and prepared as previously described [27]. After growing until stationary phase (16 h for $S$. sanguinis and 4 days for $P$. gingivalis, anaerobic incubation) the bacteria were washed in $0.9 \%$ $\mathrm{NaCl}$ and resuspended in a freshly prepared mixture of nine volumes of pooled frozen human saliva (13 donors) and one volume of pooled frozen serum (five donors) to a concentration of $10^{8}-10^{9} \mathrm{CFU} \mathrm{mL}^{-1}$. This bacteria saliva serum suspension was chosen to imitate the post-surgical subgingival situation. Afterwards, the disks were placed at the bottom of 24-well plates (BD, Basel, Switzerland) and exposed to the bacterial suspensions for $2 \mathrm{~h}$ at $35^{\circ} \mathrm{C}$. The plates were put on a shaker at 240 impulses/min to maintain the homogeneity of the suspension.

To assess the inhibitory action of the ozone system, the disks were handled as previously described [28]. Bacteria on the top side were then exposed to the gaseous ozone for 6 or $24 \mathrm{~s}$. In addition to the untreated control disk, one sample was treated with chlorhexidine $(2 \%, 30 \mathrm{~s})$ for comparison. This relatively high concentration was chosen because the $0.2 \%$ usually used to irrigate subgingival pockets have been considered only weakly bactericidal or ineffective [12]. Each condition was tested in at least four independent experiments.

To harvest adherent bacteria, each disk was suspended in $3 \mathrm{ml} 0.9 \% \mathrm{NaCl}$, vortexed for $60 \mathrm{~s}$ and sonicated for $15 \mathrm{~s}$ (30 W, 20 kHz; VibracellTM, Ultrasonic Processor, Sonics, Newtown, PA, USA). Viable bacteria were determined by culturing appropriate dilutions. Colonies were counted after 2 days ( $S$. sanguinis) and 10 days ( $P$. gingivalis) of incubation and CFU was calculated per disk. Minimal CFU detectable was $\geq 30 \mathrm{CFU}$ per disk.

\section{Cellular experiments}

In vitro experiments were performed by culturing human osteosarcoma cells (MG-63, ATCC) on each material. Cells

Table 1 Dental implant materials used in this study and average surface roughness Sa (micrometers)

\begin{tabular}{|c|c|c|c|c|}
\hline Type of material & Surface property & $\mathrm{Sa}^{\mathrm{a}}(\mu \mathrm{m})$ & Abbreviation & Manufacturer \\
\hline $\begin{array}{l}\text { Titanium (commercial pure } \\
\text { titanium, ASTM grade II) }\end{array}$ & $\begin{array}{l}\text { Sand-blasted, large-grit, acid-etched } \\
\text { Polished }\end{array}$ & $\begin{array}{l}1.554( \pm 0.029) \\
0.012( \pm 0.001)\end{array}$ & $\begin{array}{l}\text { Ti-SLA } \\
\text { Ti-P }\end{array}$ & $\begin{array}{l}\text { Straumann AG } \\
\text { Basel Switzerland }\end{array}$ \\
\hline \multirow{2}{*}{$\begin{array}{l}\text { Zirconia (yttria-stabilized } \\
\text { tetragonal zirconia polycrystal) }\end{array}$} & Acid-etched & $0.356( \pm 0.081)$ & $\mathrm{Zr}-\mathrm{A}$ & \\
\hline & Polished & $0.009( \pm 0.001)$ & Zr-P & \\
\hline
\end{tabular}

${ }^{\text {a }}$ Provided by Straumann AG 
were maintained as subconfluent monolayers in Minimal Essential Medium supplemented with $10 \%$ fetal calf serum and $1 \%$ penicillin-streptomycin (all Sigma-Aldrich, Buchs, Switzerland) at $37^{\circ} \mathrm{C}$ in a humidified atmosphere of $5 \%$ $\mathrm{CO}_{2}$. Medium was changed twice a week and cells were passaged at $80-90 \%$ confluence using $0.05 \%$ trypsin-EDTA (Gibco, Basel, Switzerland). Cells were used for experiments no later than passage 4 and seeded on disks at a density of 10,000 cells $/ \mathrm{cm}^{2}$. Determination of cell morphology, attachment, spreading, and proliferation was performed after incubation for 1,4 , and $24 \mathrm{~h}$. All experiments were repeated in duplicates with $n=5$ for an independent experiment.

For the evaluation whether cell morphology was affected by the substrate type, cells were fixed with $4 \%$ paraformaldehyde supplemented with $0.5 \%$ glutaraldehyde and dehydrated in a grade series of ethanol (50-100\%). After sputter coating with gold-palladium, the specimens were examined by scanning electron microscopy (Philips XL-30, Netherlands). Images were recorded at $\times 500$ magnification.

Cell attachment and spreading was examined by immunocytochemical staining of fixed cell cultures by the use of $4 \%$ paraformaldehyde. Nuclei staining was performed using 4',6diamidin-2phenylindol (DAPI), and actin cytoskeleton was stained with Alexa Fluor ${ }^{\circledR} 488$ phalloidin (both SigmaAldrich, Buchs, Switzerland). Each five images were recorded of all material samples at $\times 10$ magnification using a fluorescent microscope (Nikon, 90i, Switzerland). Calculation of the area of attached cells as well as counts of nuclei was performed using the Visiopharm software Version 7 (Denmark).

\section{Statistical data analysis}

One-way ANOVA was used to determine whether there was a statistically significant difference in each biological assay performed on the dental implant material compared with the titanium SLA surface. $P$ values of $<0.05$ were considered to be statistically significant.

\section{Results}

Bacterial adhesion to titanium and zirconia

During the adhesion period of $2 \mathrm{~h}$, bacterial viability and the $\mathrm{pH}$ in the bacteria saliva serum suspension remained constant. The suspension can be considered as a resting cell suspension [27].

Adhesion of $S$. sanguinis and $P$. gingivalis cells to titanium SLA surface was significantly higher by a factor $2-4$ than on titanium-polished surface and zirconia both surfaces $(p<$ 0.01 ; Fig. 2). Adhesion of $S$. sanguinis and $P$. gingivalis cells occurred to a higher extent on the rougher surface of both dental materials than on the polished surfaces.
Effects of gaseous ozone on bacteria adhered to titanium or zirconia disks

A dose-dependent effect was expected to be detectable by applying the minimal and maximal time settings of the ozone generator. Indeed a gradual difference is seen in the results summarized in Tables 2 and 3.

While chlorhexidine treatment reduced viable $S$. sanguinis counts to below detection limits, gaseous ozone application only resulted in reductions of $0-91.7 \%$. The application of gaseous ozone during the longer time of $24 \mathrm{~s}$ on $S$. sanguinis cells adhered to zirconia surface showed the highest decontamination effects of $90.7 \%$ (acid-etched surface) and 91.7\% (polished surface).

On the other hand, $P$. gingivalis was much more sensitive to ozone treatment, as gaseous ozone applied for $24 \mathrm{~s}$ was able to eliminate $P$. gingivalis cells to below detection limit from all surfaces.

Surface topography of the disks after ozone treatment

SEM analysis (Fig. 3) demonstrated a characteristic microstructure of the SLA surfaces obtained by the largegrit sandblasting process resulting in cavities, which were overlaid with micro pits due to the acid etching treatment. On the other hand, zirconia disks were only etched resulting in a microstructured surface. Consequently macro roughness of SLA surfaces was significantly higher on SLA titanium surfaces than on etched zirconia surfaces. Quantitative measurements of the surface roughness resulted in fivefold higher roughness on titanium SLA surfaces $(\mathrm{Sa}=1.554 \mu \mathrm{m})$ compared to etched zirconia $(\mathrm{Sa}=0.356 \mu \mathrm{m})$ as expected (Table 1). SEM (Fig. 3) and surface roughness of the polished titanium and zirconia indicated no morphological differences between both surfaces as a result of the grinding process. Both surfaces were smooth and even demonstrating very low and equivalent surface roughness, whereby polished zirconia showed small remains of aluminum oxide.

The surfaces of titanium (SLA and polished) and zirconia (acid-etched and polished) showed no changes by the treatment with gaseous ozone as observed by SEM (Fig. 3).

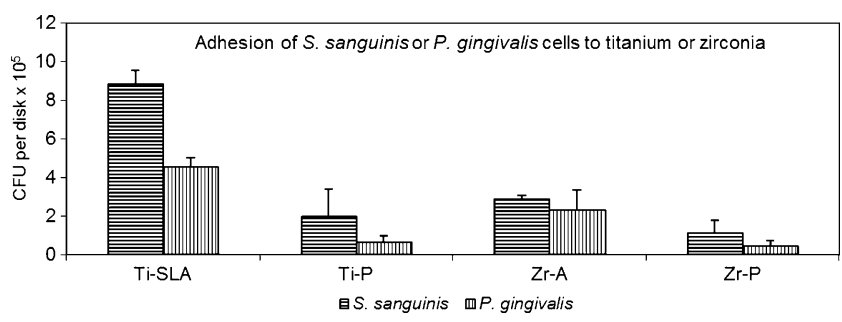

Fig. 2 Adhesion of bacterial cells during $2 \mathrm{~h}$ in a saliva serum suspension on conditioned titanium SLA (Ti-SLA) and polished (Ti-P) surfaces in comparison to zirconia acid-etched $(\mathrm{Zr}-\mathrm{A})$ and polished (Zr-P) surfaces. Mean and S.D. are given $(n=4)$ 
Table 2 Viable S. sanguinis cells released from untreated and treated surfaces

\begin{tabular}{|c|c|c|c|c|c|c|c|c|}
\hline \multirow[t]{2}{*}{ Treatment } & \multicolumn{2}{|l|}{ Ti-SLA $^{\mathrm{a}}$} & \multicolumn{2}{|l|}{ Ti-P } & \multicolumn{2}{|l|}{$\mathrm{Zr}-\mathrm{A}$} & \multicolumn{2}{|l|}{$\mathrm{Zr}-\mathrm{P}$} \\
\hline & $\begin{array}{l}\text { Viable } \\
\text { bacteria }\end{array}$ & $\begin{array}{l}\% \text { killed } \\
\text { bacteria }\end{array}$ & $\begin{array}{l}\text { Viable } \\
\text { bacteria }\end{array}$ & $\begin{array}{l}\% \text { killed } \\
\text { bacteria }\end{array}$ & $\begin{array}{l}\text { Viable } \\
\text { bacteria }\end{array}$ & $\begin{array}{l}\% \text { killed } \\
\text { bacteria }\end{array}$ & $\begin{array}{l}\text { Viable } \\
\text { bacteria }\end{array}$ & $\begin{array}{l}\% \text { killed } \\
\text { bacteria }\end{array}$ \\
\hline $\begin{array}{l}\text { Untreated } \\
\text { control }\end{array}$ & $8.8^{\mathrm{b}} \times 10^{5}$ & 0 & $2.0 \times 10^{5}$ & 0 & $2.9 \times 10^{5}$ & 0 & $1.1 \times 10^{5}$ & 0 \\
\hline $\begin{array}{l}\text { Chlorhexidine } \\
2 \%\end{array}$ & b.d.1. ${ }^{\mathrm{c}}$ & $>99.99$ & b.d.1. ${ }^{\mathrm{c}}$ & 99.99 & b.d.1. ${ }^{\mathrm{c}}$ & 99.99 & b.d.1. ${ }^{\mathrm{c}}$ & 99.97 \\
\hline Ozone $6 \mathrm{~s}$ & $2.3 \times 10^{5}$ & 73.9 & $3.3 \times 10^{5}$ & 0 & $4.3 \times 10^{4}$ & 85.2 & $5.5 \times 10^{4}$ & 50.0 \\
\hline Ozone $24 \mathrm{~s}$ & $9.0 \times 10^{4}$ & 89.8 & $8.0 \times 10^{4}$ & 60.0 & $2.7 \times 10^{4}$ & 90.7 & $9.1 \times 10^{3}$ & 91.7 \\
\hline
\end{tabular}

Untreated samples served as negative control whereas treatment with chlorhexidine served as positive control

${ }^{\text {a }}$ Materials as in Table 1

${ }^{\mathbf{b}}$ Mean of four experiments

${ }^{\mathrm{c}}$ Below detection limit (30 CFU/disk)

\section{Cell morphology and spreading}

When MG-63 cell were seeded on different substrates, cells showed a typical spherical morphology after $1 \mathrm{~h}$ in the process of initial adhesion (Fig. 4a, b, g, h). Thereby the morphology of cells did not differ in comparison between titanium and zirconia surfaces. Another $3 \mathrm{~h}$ later $(4 \mathrm{~h}$ after seeding), individual cells were flat in appearance on polished surface indicating an efficient cell material interaction (Fig. 4c, i). However, cells on titanium-sandblasted, large-grit, acid-etched (Ti-SLA) and zirconia-acidetched (Zr-A) surfaces did not show the same flattened shape as on polished surfaces, but started to form filopodia to explore the surface (Fig. 4d, k). By $24 \mathrm{~h}$, cells on all surfaces had become flattened and were uniformly distributed across the surface, whereby cells on Ti-SLA preferred the large cavities. Moreover, cells partially formed cell clusters, although never reaching confluence (Fig. 4e, f, 1, m).
Cell spreading was examined at all time points and the percent area was quantified of surface covered with cells applying the image analysis (Fig. 5). After $1 \mathrm{~h}$, the cell cytoskeleton expansion was lower on titanium compared to zirconia surfaces. Thereby, the lowest expansion was detected on titanium-polished (Ti-P; $0.56 \%$ ) disks and the highest on $\mathrm{Zr}-\mathrm{A}$ (3.36\%). However, cells on all surfaces explored the surfaces after $24 \mathrm{~h}$ of proliferation without a significant effect by the surface treatment. Ozone-treated surfaces tended to result in a higher cell spreading after $24 \mathrm{~h}$ especially on polished surfaces (Fig. 5). Higher percentage of cell spreading was always observed on polished surfaces than on Ti-SLA and $\mathrm{Zr}$-A samples due to the adaptation of the cell structure into the macro and micro cavities causing a larger cell surface.

\section{Cell proliferation}

Immunocytochemistry (DAPI staining) and quantification of nuclei per image area were performed to assess the

Table 3 Viable $P$. gingivalis cells released from untreated and treated surfaces

\begin{tabular}{|c|c|c|c|c|c|c|c|c|}
\hline \multirow[t]{2}{*}{ Treatment } & \multicolumn{2}{|l|}{ Ti-SLA $^{\mathrm{a}}$} & \multicolumn{2}{|l|}{ Ti-P } & \multicolumn{2}{|l|}{$\mathrm{Zr}-\mathrm{A}$} & \multicolumn{2}{|l|}{$\mathrm{Zr}-\mathrm{P}$} \\
\hline & $\begin{array}{l}\text { Viable } \\
\text { bacteria }\end{array}$ & $\begin{array}{l}\% \text { killed } \\
\text { bacteria }\end{array}$ & $\begin{array}{l}\text { Viable } \\
\text { bacteria }\end{array}$ & $\begin{array}{l}\% \text { killed } \\
\text { bacteria }\end{array}$ & $\begin{array}{l}\text { Viable } \\
\text { bacteria }\end{array}$ & $\begin{array}{l}\% \text { killed } \\
\text { bacteria }\end{array}$ & $\begin{array}{l}\text { Viable } \\
\text { bacteria }\end{array}$ & $\begin{array}{l}\% \text { killed } \\
\text { bacteria }\end{array}$ \\
\hline $\begin{array}{l}\text { Untreated } \\
\text { control }\end{array}$ & $4.6^{\mathrm{b}} \times 10^{5}$ & 0 & $6.4 \times 10^{4}$ & 0 & $2.3 \times 10^{5}$ & 0 & $4.7 \times 10^{4}$ & 0 \\
\hline $\begin{array}{l}\text { Chlorhexidine } \\
2 \%\end{array}$ & b.d.1. ${ }^{\mathrm{c}}$ & $>99.99$ & b.d.1. ${ }^{\mathrm{c}}$ & $\geq 99.95$ & b.d.1. ${ }^{\mathrm{c}}$ & $\geq 99.99$ & b.d.1. ${ }^{c}$ & $\geq 99.94$ \\
\hline Ozone $6 \mathrm{~s}$ & $6.2 \times 10^{2}$ & 99.9 & $1.0 \times 10^{3}$ & 98.4 & $3.7 \times 10^{2}$ & 99.84 & 45 & 99.9 \\
\hline Ozone $24 \mathrm{~s}$ & b.d.l. ${ }^{\mathrm{c}}$ & $>99.99$ & b.d.1. ${ }^{\mathrm{c}}$ & $\geq 99.95$ & b.d.1. ${ }^{\mathrm{c}}$ & $\geq 99.99$ & b.d.1. ${ }^{\mathrm{c}}$ & $\geq 99.94$ \\
\hline
\end{tabular}

Untreated samples served as negative control whereas treatment with chlorhexidine served as positive control

${ }^{\text {a }}$ Materials as in Table 1

${ }^{\mathrm{b}}$ Mean of four experiments

${ }^{\mathrm{c}}$ Below detection limit (30 CFU/disk) 

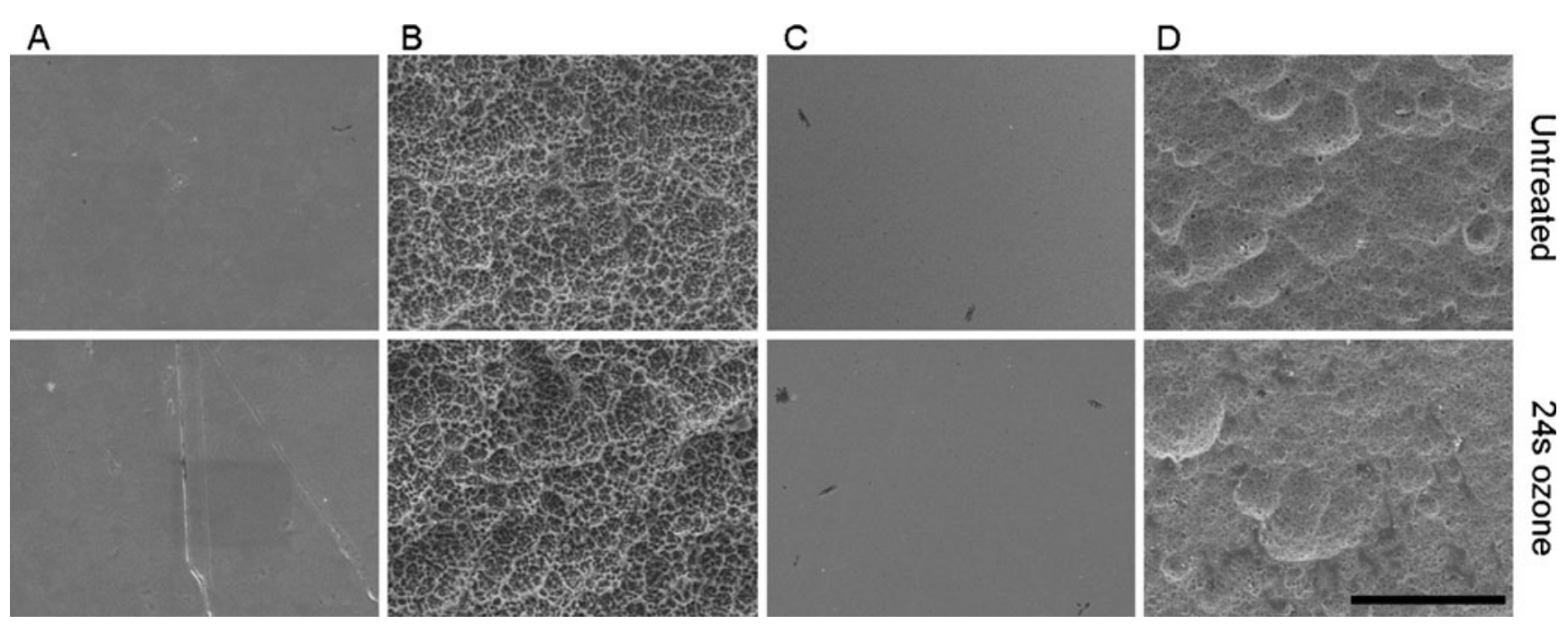

Fig. 3 Representative scanning electron micrographs showing the surface roughness of untreated materials (top row) and surfaces treated by ozone for $24 \mathrm{~s}$ (bottom row). a Ti-P, b Ti-SLA, c Zr-P, d Zr-A. Magnification $\times 500 ;$ bar $=50 \mu \mathrm{m}$

proliferation behavior of the MG-63 cells seeded onto different surfaces. Figure 6 shows the average nuclei count per substrate. Initial adhesion after $1 \mathrm{~h}$ showed the highest cell numbers on Zr-A treated with gaseous ozone for $24 \mathrm{~s}$ (94 nuclei) and the lowest number on untreated Ti-P samples (16 nuclei). Surface treatment with gaseous ozone did not affect initial cell adhesion on Ti-SLA, but did slightly enhance cell numbers on all other surfaces (Ti-P, ZrA, zirconia polished (Zr-P)). After $4 \mathrm{~h}$, the cell number was observed to be almost similar on all surfaces independent of the treatment. Nevertheless, after $24 \mathrm{~h}$ the highest cell numbers was detected on all Ti-SLA surfaces (125-137 nuclei). Slightly lower cell numbers were quantified on all ozone-treated samples (100-127 nuclei), whereas the lowest cell proliferation was shown on Zr-P (control; 64 nuclei). Based on the initial cell number after $1 \mathrm{~h}$ of seeding, all cultures demonstrated a twofold cell growth after $24 \mathrm{~h}$ except cultures on Zr-A (24 s ozone-treated), which showed no proliferation.

\section{Discussion}

Failure of dental implants may occur by peri-implantitis and/or lack of osseointegration. Since bacterial infection is one of the main causes of peri-implantitis, both reduced bacterial colonization on and elimination of bacteria from the surface of dental implants are required to treat, and even to prevent, peri-implantitis. Therefore, it was the aim of this study to investigate the antimicrobial efficacy of gaseous ozone on bacteria adhered to various titanium and zirconia surfaces. It could be demonstrated that gaseous ozone disclosed a selective efficacy to control adherent bacteria on both materials without causing any surface damages. The results of cellular response revealed an essential base for sufficient tissue regeneration.

The bacteria saliva serum suspension was used to simulate in vivo conditions as closely as possible. As soon as the material is implanted, it comes into contact with saliva and blood and the surface of the material will be covered with some of their compounds to which bacteria, present in abundance, then adhere. This experimental system allowed the detection of 3-4.5 log reduction of adhered bacteria by treatment with CHX or ozone.

Adhesion of bacteria on titanium implants has already been described both in vivo and in vitro. Dominant factors influencing bacterial adhesion are surface free energy and chemical composition, and particularly surface roughness of the material $[9,27,29,30]$. In several different test systems, rough surfaces promoted bacterial adhesion whereas smooth surfaces minimized it. We found a lower bacterial adhesion on titanium-polished surface ( $\mathrm{Sa}, 0.012 \mu \mathrm{m})$ in comparison to SLA surface ( $\mathrm{Sa}, 1.554 \mu \mathrm{m})$ in the presence of absorbed proteins which is in line with the few previous reports. Comparative studies for zirconia are scarce. Hisbergues et al. [26] concluded that zirconia might show a lower bacterial colonization but saw a need for further studies, particularly in the presence of absorbed proteins of a saliva serum pellicle. The present investigation provides some of these data for zirconia. It confirms expectations that zirconia, under the conditions used, showed lower bacterial adhesion than titanium. The results demonstrate that zirconia may be a suitable material for implant abutments with a lower colonization potential. The fact that $S$. sanguinis adhered to a higher extent to both materials than $P$. gingivalis could be related to its nature as a first colonizer.

To eliminate bacteria from the subgingival implant surfaces, mechanical instruments have been generally used. 
Fig. 4 Representative SEM

images of osteoblastic cells

cultured on polished and etched titanium as well as zirconia.

a Ti-P, b Ti-SLA, g Zr-P, h Zr-A seeded with cells for $1 \mathrm{~h}$;

demonstrating the initial adhesion. c Ti-P, d Ti-SLA, i Zr-P, $\mathbf{k} \mathrm{Zr}$-A seeded with cells for $4 \mathrm{~h}$; demonstrating cell attachment. e Ti-P, f Ti-SLA, I Zr-P, m Zr-A seeded with cells for $24 \mathrm{~h}$; demonstrating cell growth. bar $=10 \mu \mathrm{m}(\mathrm{a}, \mathrm{b}, \mathrm{g}, \mathrm{h})$ and $100 \mu \mathrm{m}$ (c-f, i-m)
Titanium
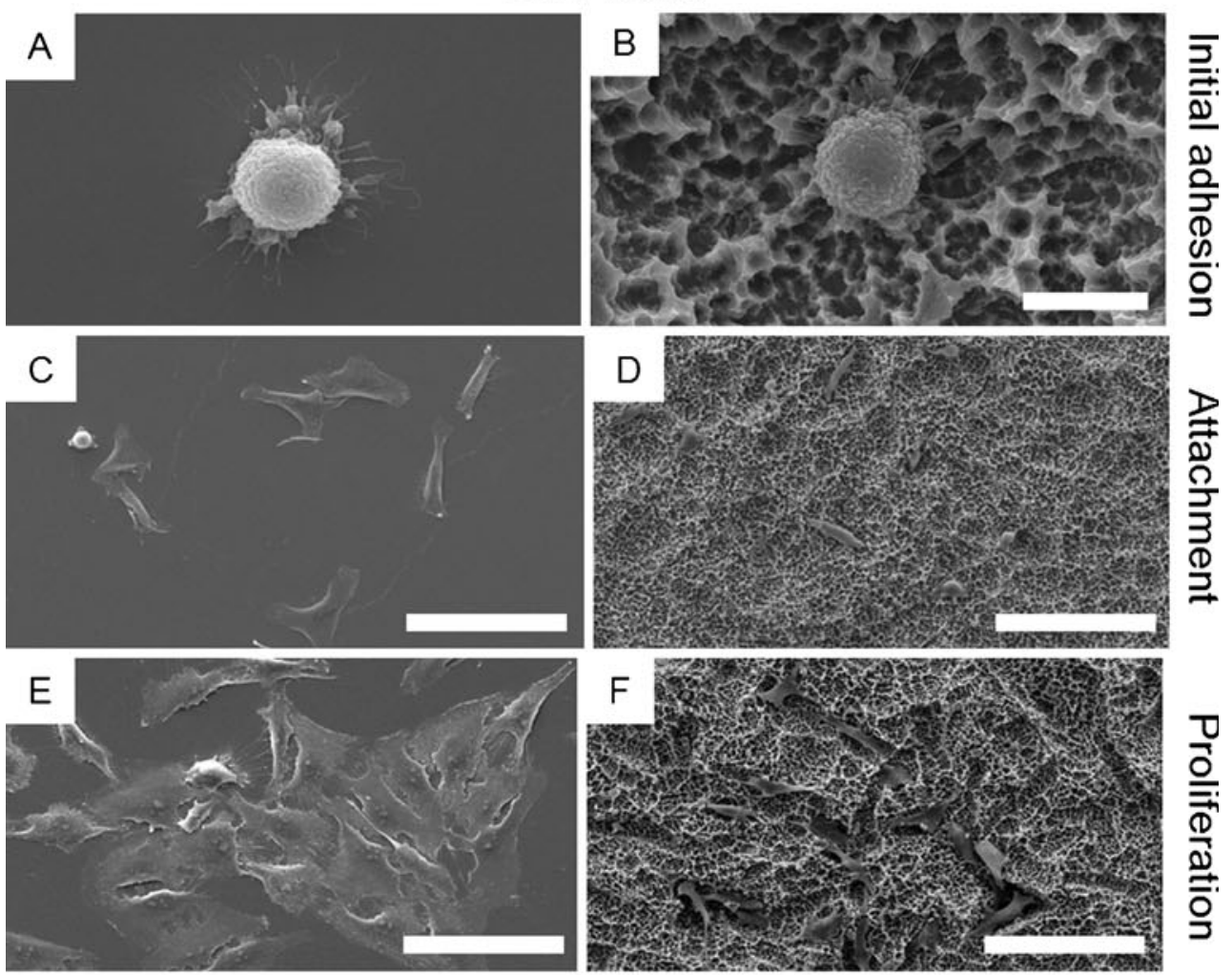

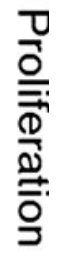

\section{Zirconia}
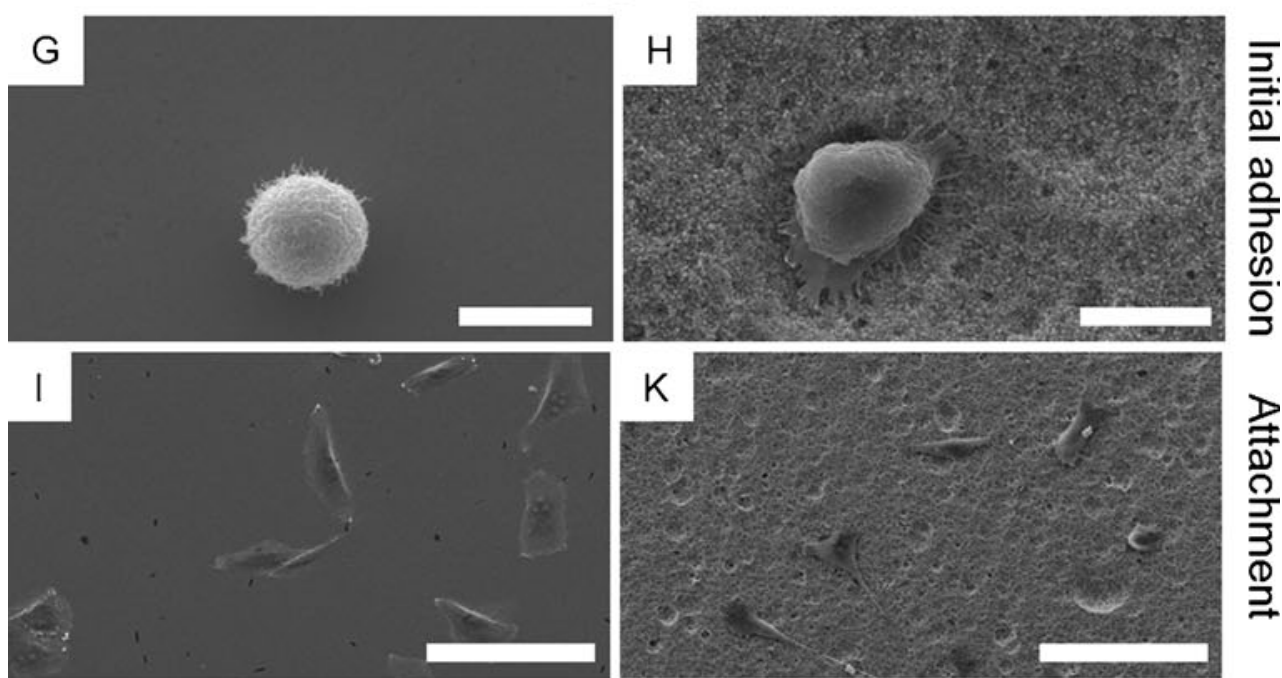

恋
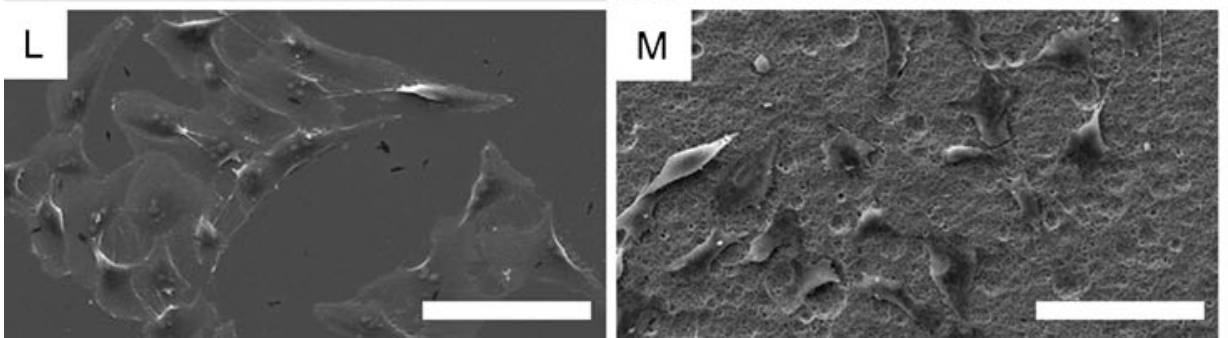

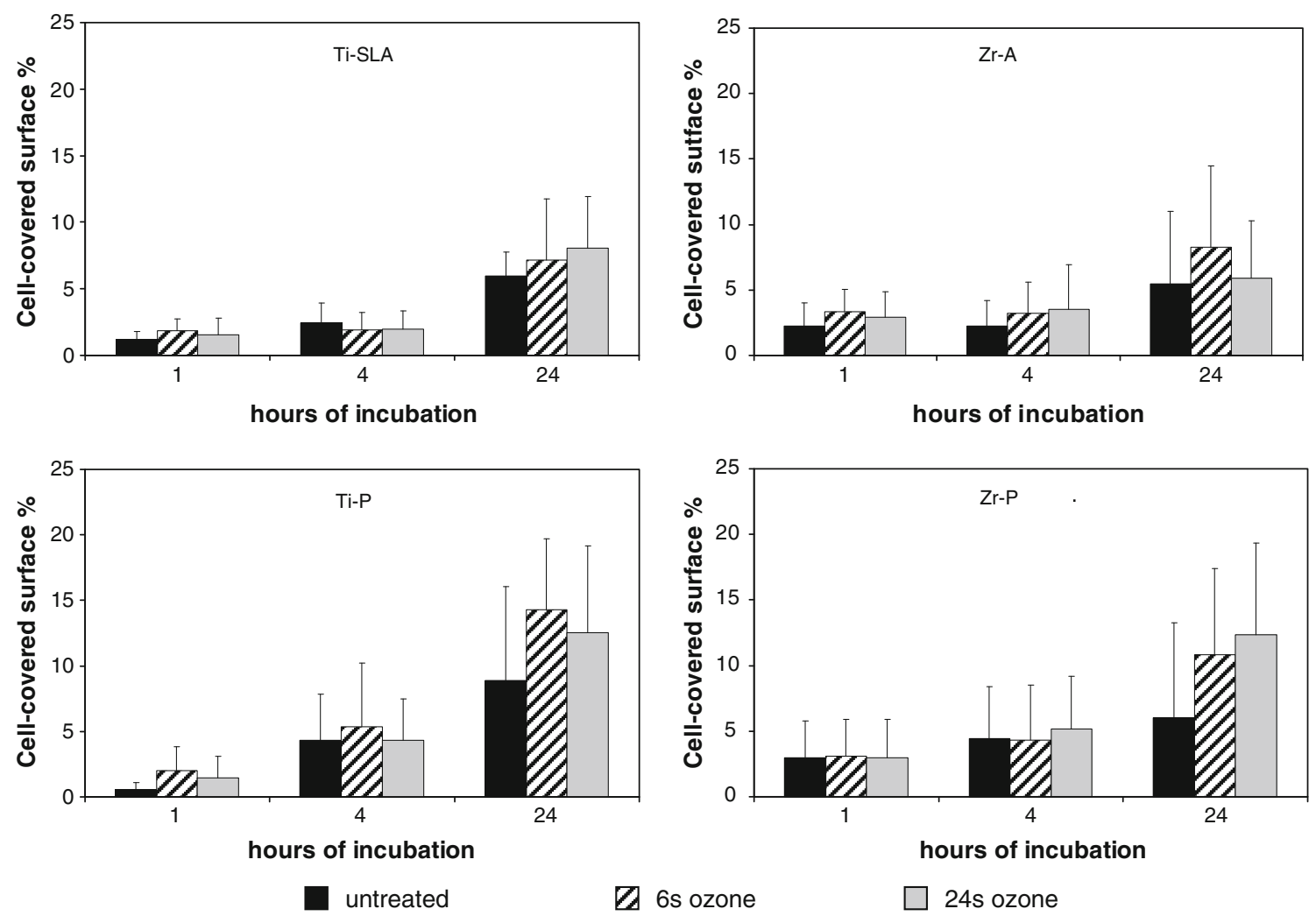

Fig. 5 Quantification of cell spreading per surface by actin staining. MG-63 cultured for 1, 4, and 24 h on different surfaces: Ti-SLA, Ti-P, Zr-A, and Zr-P without and after ozone treatment for 6 or $24 \mathrm{~s}$

Some of these instruments have been reported to damage the implant surface structure and cause metallic contamination or adhesion of abrasive powder to the implants fixture. In the present in vitro study, gaseous ozone was used which had quite some bactericidal activity, while material surfaces both, titanium and zirconia, did not change by the treatment.

The study demonstrated a drastic reduction of adhered $S$. sanguinis on titanium material, both surfaces, by gaseous ozone, particularly after application for $24 \mathrm{~s}$. However, the reduction did not match with that achieved by $\mathrm{CHX}$. The results are in accordance with other in vitro findings showing that ozone had an antibacterial effect on bacteria suspended in pure water, but was less effective when cells were embedded in a biofilm or organic material [31, 32]. The saliva serum mixture used for the adhesion assays could have a protective effect due to strong interactions of the ozone with organic material. Similar lack of efficacy on carious lesion by gaseous ozone was observed in two in vivo studies where a different ozone generator (HealOzone) was employed [33, 34]. These authors suggested that interactions with organic material reduced the antimicrobial activity of ozone gas in vivo. It may be a common problem when gaseous ozone is applied in the oral cavity in the presence of organic material and will prevent achieving rapid and effective disinfection of colonized surfaces (teeth and implants).

However, under the current conditions gaseous ozone was able to eliminate $P$. gingivalis cells from all surfaces. It produced a similar decontaminating effect as $2 \%$ CHX used as a control. The higher sensitivity to ozone of $P$. gingivalis cells could be explained by the anaerobic nature of these bacteria.

Some studies documented a significant effect of ozone gas against oral bacteria [35-37]. The results are difficult to compare, because the ozone concentration was higher (e.g., 2,100 ppm HealOzone) and/or the treatment time was longer (e.g., $10 \mathrm{~min}$ ), and/or other bacterial species were tested in other oral or in vitro environment. For a clinical application, this may suggest use of equipment providing higher ozone dose to achieve elimination of $S$. sanguinis cells.

The application of gaseous ozone during the longer time of 24 s on $S$. sanguinis cells adhered to zirconia surface showed around $91 \%$ killed bacteria. The question remains unanswered whether such a reduction of viable bacteria is of biological significance. It is most likely, that bacteria established on a surface, even when reduced by $91 \%$, will re-grow within hours once environmental conditions become favorable again. It should be of substantial interest to eliminate 

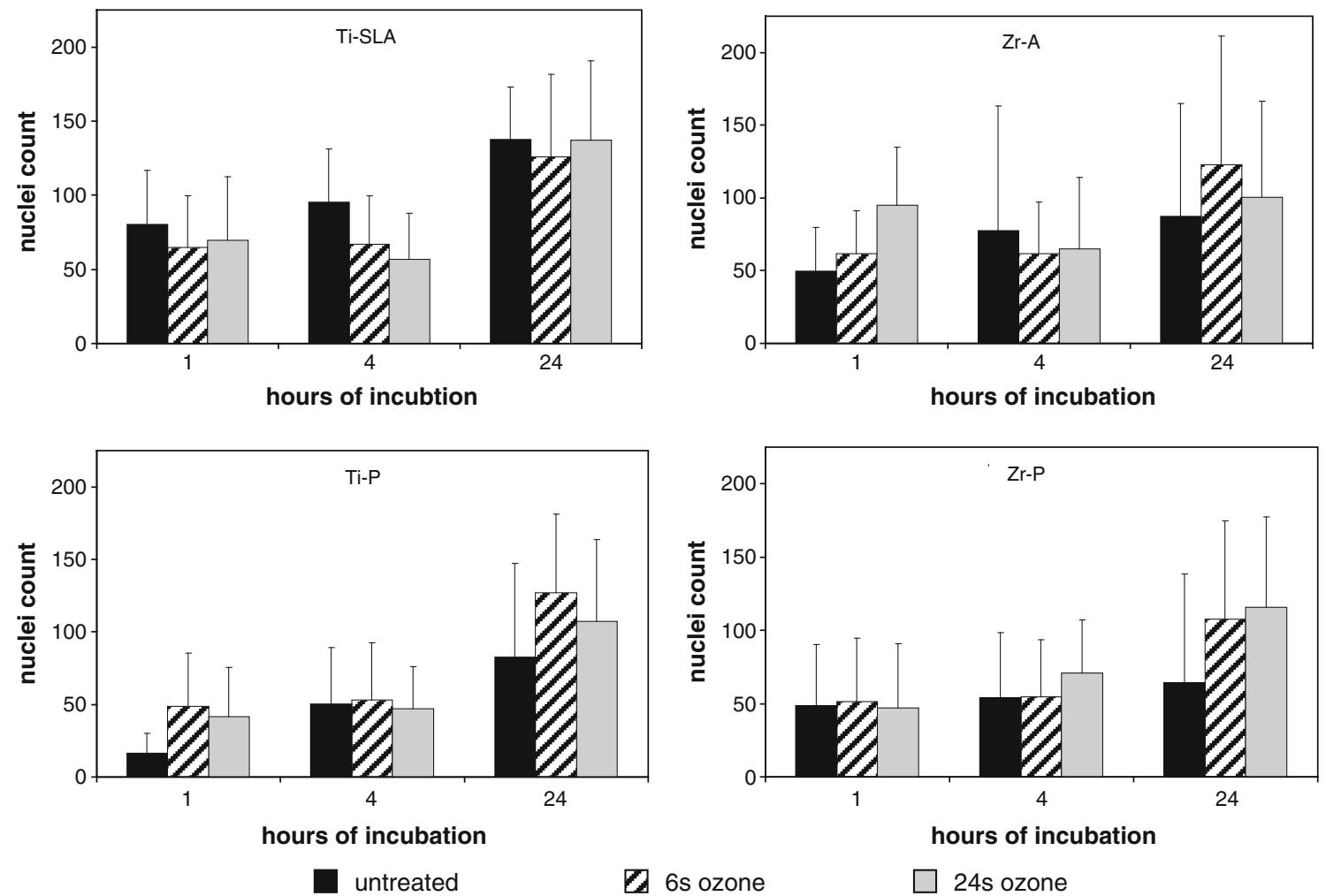

Fig. 6 Quantification of nuclei per image area. MG-63 cultured for 1, 4, and $24 \mathrm{~h}$ on different surfaces: Ti-SLA, Ti-P, Zr-A, and Zr-P without and after ozone treatment for 6 or $24 \mathrm{~s}$

not only bacteria associated with peri-implantitis but also early colonizers like $S$. sanguinis. Early bacterial colonization of peri-implant pockets is characterized by an increase of streptococci creating the pre-conditions for adhesion of periodontal pathogens which in turn can induce periimplantitis [38, 39]. It could be assumed that a longer period of application of gaseous ozone or a higher dose could have an improved effect on $S$. sanguinis adhered to zirconia surface. The time of application of gaseous ozone was used according to the manufacturer's instructions. A prolonged time was not addressed in this study and represents an area for future research focused on zirconia implant material. However, regarding the potential toxicity of ozone, ozone should not reach a concentration above permitted levels both in the patients' respiration tract and in the surrounding air of the dentist. Several guidelines recommend safety limits of $0.1 \mathrm{ppm}$ ozone in air for an 8-h continuous exposure. What ozone levels in the oral cavity would result from the use of the Ozotop device has, to our knowledge, not been determined. While HealOzone was determined to be safe to use, another generator (without adequate suction) resulted in ozone concentrations above permitted levels [40]. Therefore a safe dose and time of exposure should be considered and carefully evaluated.

Besides, it has to be taken into account that the implant material is in direct contact with the surrounding tissue such as bone and soft tissue. In this context, the implant has to remain biocompatible and non-toxic also after treatment with ozone. Therefore, the present study also included a supplemental evaluation of a possible effect on osteoblastlike cell behavior with regard to cell adhesion and proliferation. Because not only surface topography and roughness but also surface chemistry can affect the tissue regeneration [41]. Cell adhesion results obtained by SEM and immunocytochemistry of the cytoskeleton showed no differences between zirconia and titanium material. The study confirmed that surface roughness had a more significant influence on cell adhesion and proliferation, which was recently shown by other in vitro studies [42-44]. The experiments showed a slight reduction on cell spreading on rough (Ti-SLA, Zr-A) versus smooth surfaces confirming previous studies $[45,46]$ where cells on smooth surfaces were more flattened, but mainly spherical on rough surfaces. Independent of the material or topography, cell showed a good and consistent cell proliferation. Interestingly, cell proliferation after $24 \mathrm{~h}$ showed no influence of previous ozone treatment on titanium SLA surfaces. However, cell numbers on all other surfaces slightly increased when treated with ozone prior to the seeding. This observation indicates a slight effect on surfaces with lower roughness (Zr-A, Ti-P, Zr-P). This might be due to a cleaning effect of the surface treatment by ozone. Ozone 
treatment for 6 or $24 \mathrm{~s}$ did not harm osteoblast-like cells, whereby the presented study did not yet include the differentiation aspects concerning extracellular matrix maturation, growth factor release and the expression of specific osteoblastic markers.

Three of the test surfaces, titanium (polished) and zirconia (acid etched or polished) yielded lower bacterial adhesion and, thus, may be suitable material for implant abutment. Application of gaseous ozone at $140 \mathrm{ppm}$ for $24 \mathrm{~s}$ eliminated $P$. gingivalis but not $S$. sanguinis to below detection limit from all surfaces. This ozone treatment did not negatively affect adhesion and proliferation of osteoblast-like MG-63 cells on the titanium and zirconia surfaces tested. Further optimization is required to develop the procedure into a potential treatment of peri-implant infections.

Acknowledgements We thank the ITI Foundation, Switzerland, (Grant No.: 518/2007) and the SSO Fonds (grant no.: 248-09) for financial support and TIP TOP TIPS Sàrl, Rolle, Switzerland, for supplying the ozone equipment.

Conflict of interests The authors declare that they have no conflict of interest.

\section{References}

1. Al-Nawas B, Kämmerer PW, Morbach T, Ladwein C, Wegener J, Wagner W (2010) Ten-year retrospective follow-up study of the TiOblast dental implant. Clin Implant Dent Relat Res. doi:10.1111/ j.1708-8208.2009.00237.x

2. Jemt $T$ (2008) Single implants in the anterior maxilla after 15 years of follow-up: comparison with central implants in the edentulous maxilla. Int J Prosthodont 21:400-408

3. Buddula A, Assad DA, Salinas TJ, Garces YI, Volz JE, Weaver AL (2010) Survival of dental implants in irradiated head and neck cancer patients: a retrospective analysis. Clin Implant Dent Relat Res. doi:10.1111/j.1708-8208.2010.00307.x

4. Karoussis IK, Muller S, Salvi GE, Heitz-Mayfield LJ, Bragger U, Lang NP (2004) Association between periodontal and periimplant conditions: a 10-year prospective study. Clin Oral Implants Res 15:1-7

5. Berglundh T, Gislason O, Lekholm U, Sennerby L, Lindhe J (2004) Histopathological observations of human peri-implantitis lesions. J Clin Periodontol 31:341-347

6. Albrektsson T, Isidor F (1994) Consensus report: implant therapy. In: Lang NP, Karring T (eds) Proceedings of the 1st European Workshop on Periodontology. Quintessence Publishing Co Ltd, London, pp 365-369

7. Quirynen M, De Soete M, van Steenberghe D (2002) Infectious risks for oral implants: a review of the literature. Clin Oral Implants Res 13:1-19

8. Costerton JW, Montanaro L, Arciola CR (2005) Biofilm in implant infections: its production and regulation. Int J Artif Organs 28:1062-1068

9. Teughels W, Van Assche N, Sliepen I, Quirynen M (2006) Effect of material characteristics and/or surface topography on biofilm development. Clin Oral Implant Res 17:68-81

10. Norowski PA, Bumgardner JD (2009) Biomaterial and antibiotic strategies for peri-implantitis: a review. J Biomed Mater Res B Appl Biomater 88:530-543
11. Schwarz F, Bieling K, Sculean A, Herten M, Becker J (2004) Treatment of periimplantitis with laser or ultrasound. A review of the literature (Article in German). Schweiz Monatsschr Zahnmed 114:1228-1235

12. Renvert S, Roos-Jansåker AM, Claffey N (2008) Non-surgical treatment of peri-implant mucositis and peri-implantitis: a literature review. J Clin Periodontol 35(8 Suppl):305-315

13. Roos-Jansåker AM, Renvert S, Egelberg J (2003) Treatment of peri-implant infections: a literature review. J Clin Periodontol 30:467-485

14. Persson GR, Samuelsson E, Lindahl C, Renvert S (2010) Mechanical non-surgical treatment of peri-implantitis: a singleblinded randomized longitudinal clinical study. II. Microbiological results. J Clin Periodontol 37:563-573

15. Mouhyi J, Sennerby L, Pireaux JJ, Dourov N, Nammour S, Van Reck J (1998) An XPS and SEM evaluation of six chemical and physical techniques for cleaning of contaminated titanium implants. Clin Oral Implants Res 9:185-194

16. Mouhyi J, Sennerby L, Wennerberg A, Louette P, Dourov N, van Reck J (2000) Re-establishment of the atomic composition and the oxide structure of contaminated titanium surfaces by means of carbon dioxide laser and hydrogen peroxide: an in vitro study. Clin Implant Dent Relat Res 2:190-202

17. Deppe H, Horch HH (2007) Laser applications in oral surgery and implant dentistry. Lasers Med Sci 22:217-221

18. Stübinger S, Sader R, Filippi A (2006) The use of ozone in dentistry and maxillofacial surgery: a review. Quintessence Int 37:353-359

19. Azarpazhooh A, Limeback H (2008) The application of ozone in dentistry: a systematic review of literature. J Dent 36:104-116

20. Emerson M, Sprone OJ, Buck CE (1982) Ozone inactivation of cell-associated viruses. Appl Environ Microbiol 43:603-608

21. Dyas A, Boughton BJ, Das BC (1983) Ozone killing action against bacterial and fungal species; microbiological testing of a domestic ozone generator. J Clin Pathol 36:1102-1104

22. Persson LG, Berglundh T, Lindhe J, Sennerby L (2001) Re-osseointegration after treatment of peri-implantitis at different implant surfaces. An experimental study in the dog. Clin Oral Implants Res 12:595-603

23. Ivanoff CJ, Sennerby L, Lekholm U (1996) Influence of soft tissue contamination on the integration of titanium implants. An experimental study in rabbits. Clin Oral Implant Res 7:128-132

24. Bowers KT, Keller JC, Randolph BA, Wick DC, Michaels CM (1992) Optimization of surface micromorphology for enhanced osteoblast responses in vitro. Int $\mathrm{J}$ Oral Maxillofac Implants $73: 302-310$

25. Filippi A (2001) Der Einfluss von ozoniertem Wasser auf die epitheliale Wundheilung. Dtsch Zahnärztl Z 56:104-108

26. Hisbergues M, Vendeville S, Vendeville P (2008) Zirconia: established facts and perspectives for a biomaterial in dental implantology. J Biomed Mater Res B Appl Biomater 88:519-529

27. Hauser-Gerspach I, Kulik EM, Weiger R, Decker E-M, Von Ohle C, Meyer J (2007) Adhesion of Streptococcus sanguinis to dental implant and restorative materials. Dent Mater J 26:361-366

28. Hauser-Gerspach I, Stübinger S, Meyer J (2010) Bactericidal effects of different laser systems on bacteria adhered to dental implant surfaces. An in vitro study comparing zirconia to titanium. Clin Oral Implant Res 21:277-283

29. Sardin S, Morrier J-J, Benay G, Barsotti O (2004) In vitro streptococcal adherence on prosthetic and implant materials. Interactions with physicochemical surface properties. J Oral Rehab 31:140-148

30. Mabboux F, Ponsonnet L, Morrier JJ, Jaffrezic N, Barsotti O (2004) Surface free energy and bacterial retention to saliva-coated dental implant materials-an in vitro study. Colloids Surf B Biointerfaces 39:199-205 
31. Hems RS, Gulabivala K, Ng YL, Ready DR, Spratt DA (2005) An in vitro evaluation of the ability of ozone to kill a strain of Enterococcus faecalis. Int Endod J 38:22-29

32. Müller P, Guggenheim B, Schmidlin PR (2007) Efficacy of gasiform ozone and photodynamic therapy on a multispecies oral biofilm in vitro. Eur J Oral Sci 115:77-80

33. Hauser-Gerspach I, Pfäffli-Savtchenko V, Dähnhardt JE, Meyer J, Lussi A (2009) Comparison of the immediate effects of gaseous ozone and chlorhexidine gel on bacteria in cavitated carious lesions in children in vivo. Clin Oral Invest 13:287-291

34. Baysan A, Beighton D (2007) Assessment of the ozone-mediated killing of bacteria in infected dentine associated with noncavitated occlusal carious lesions. Caries Res 41:337-341

35. Kuştarci A, Sümer Z, Altunbaş D, Koşum S (2009) Bactericidal effect of KTP laser irradiation against Enterococcus faecalis compared with gaseous ozone: an ex vivo study. Oral Surg Oral Med Oral Pathol Oral Radiol Endod 107:e73-e79

36. Huth KC, Quirling M, Maier S, Kamereck K, Alkhaye M, Paschos E, Welsch U, Miethke T, Brand K, Hickel R (2009) Effectiveness of ozone against endodontopathogenic microorganisms in a root canal biofilm model. Int Endod J 42:3-13

37. Stoll R, Venne L, Jablonski-Momeni A, Mutters R, Stachniss V (2008) The disinfecting effect of ozonized oxygen in an infected root canal: an in vitro study. Quintessence Int 39:231-236

38. van Winkelhoff AJ, Goené RJ, Benschop C, Folmer T (2000) Early colonization of dental implants by putative periodontal pathogens in partially edentulous patients. Clin Oral Implants Res 11:511-521

39. Heuer W, Elter C, Demling A, Neumann A, Suerbaum S, Hannig M, Heidenblut T, Bach FW, Stiesch-Scholz M (2007) Analysis of early biofilm formation on oral implants in man. J Oral Rehabil $34: 377-382$

40. Millar BJ, Hodson N (2007) Assessment of the safety of two ozone delivery devices. J Dent 35:195-200

41. Deligianni DD, Katsala ND, Ladas S, Sotiropoulou D, Amedee J, Missirlis YF (2001) Effect of surface roughness of the titanium alloy Ti-6Al-4 V on human bone marrow cell response and on protein adsorption. Biomaterials 22:1241-1251

42. Zhao G, Raines AL, Wieland M, Schwartz Z, Boyan BD (2007) Requirement for both micron- and submicron scale structure for synergistic responses of osteoblasts to substrate surface energy and topography. Biomaterials 28:2821-2829

43. Boyan BD, Lossdörfer S, Wang L, Zhao G, Lohmann $\mathrm{CH}$, Cochran DL, Schwartz Z (2003) Osteoblasts generate an osteogenic microenvironment when grown on surfaces with rough microtopographies. Eur Cell Mater 24:22-27

44. Rausch-Fan X, Qu Z, Wieland M, Matejka M, Schedle A (2008) Differentiation and cytokine synthesis of human alveolar osteoblasts compared to osteoblast-like cells (MG63) in response to titanium surfaces. Dent Mater 24:102-110

45. Setzer B, Bächle M, Metzger MC, Kohal RJ (2009) The geneexpression and phenotypic response of hFOB 1.19 osteoblasts to surface-modified titanium and zirconia. Biomaterials 30:979990

46. Martin JY, Schwartz Z, Hummert TW, Schraub DM, Simpson J, Lankford JJ, Dean DD, Cochran DL, Boyan BD (1995) Effect of titanium surface roughness on proliferation, differentiation, and protein synthesis of human osteoblast-like cells (MG63). J Biomed Mater Res 29:389-401 